\title{
Edukasi K3 Dalam Penggunaan Pestisida dan APD Di Kel. Gantarang Keke, Kabupaten Bantaeng
}

\author{
Waode Rustiah, Nur Qadri Rasyid \\ Teknologi Laboratorium Medis, Politeknik Kesehatan Muhammadiyah Makassar \\ *E-mail: waoderustiah79@gmail.com
}

\begin{abstract}
Pesticides is chemical substances and other materials as well as microorganisms and viruses that are used to control various plant-disturbing organisms. Early public education about pesticides is an important element to avoid increasing exposure for farmers or workers in the spraying division of plant pests. In addition, the community has never carried out early detection and feels that they are already immune and are used to the pungent smell of pesticides. This service activity is carried out with the aim of implementing a community-based education program that facilitates the community in increasing knowledge about early detection and preventive efforts against the using of pesticides that do not meet the requirements in the application of Occupational Health and Safety (K3) principles in Gantarang Keke Village, Bantaeng Regency. Methods of implementation this community service consists of two stages, namely: 1) the preparation stage includes health counseling with the lecture method to the community of Gantarang Keke Village; 2) the implementation stage includes the implementation of the implementation program in the form of implementing $\mathrm{K} 3$ correctly and safely. The results show that with education carried out through counseling about the application of K3 to the people of Gantarang Keke Village, they begin to understand about the safe and correct using of pesticides, as well as the use of Personal Protective Equipment in accordance with the requirements in $K 3$ principles.
\end{abstract}

Keywords: Counseling, K3, Pesticides

\begin{abstract}
Abstrak
Pestisida adalah zat kimia dan kandungan lain serta mikroorganisme dan virus yang digunakan dalam mengatasi berbagai hama perusak tanaman. Edukasi dini masyarakat terhadap pestisida adalah elemen penting untuk menghindari meningkatnya pajanan bagi petani atau pekerja dibagian penyemprotan hama tanaman. Selain itu, banyak masyarakat tidak melakukan deteksi awal dan merasa sudah kebal serta sudah terbiasa dengan bau pestisida yang menyengat. Pengabdian masyarakat ini bertujuan untuk mengaplikasikan program edukasi kepada masyarakat dalam menambah ilmu tentang deteksi dini akan keracunana pestisida dan upaya preventif terhadap penggunaan pestisida yang belum memenuhi syarat dalam penerapan prinsip Kesehatan dan Keselamatan Kerja $(3 K)$ di Kelurahan Gantarang Keke, Kabupaten Bantaeng. Metode pelaksanaan pengabdian masyarakat ini terdiri dari dua tahapan, yaitu: 1) tahapan persiapan meliputi penyuluhan kesehatan dengan metode ceramah kepada masyarakat Kelurahan Gantarang Keke; 2) tahapan implementasi meliputi pelaksanaan program implementasi berupa penerapan K3 secara benar dan aman. Hasilnya menunjukkan bahwa dengan adanya edukasi yang dilakukan melalui penyuluhan tentang penerapan K3 pada Masyarakat Kelurahan Gantarang Keke, pada akhirnya mereka mulai memahami tentang penggunaan pestisida yang aman dan benar, serta penggunaan APD yang sesuai dengan syarat dalam prinsip K3.
\end{abstract}

Kata kunci: Penyuluhan, K3, Pestisida

\section{PENDAHULUAN}

Pestisida adalah semua substansi zat kimia dan bahan lain serta jasad renik dan virus yang digunakan untuk memberantas atau mencegah hama-hama yang merusak tanaman atau hasil-hasil pertanian, selain itu digunakan untuk mematikan dan mencegah pertumbuhan yang tidak diiginkan. Saat ini, umumnya para petani di Indonesia beranggapan bahwa pestisida merupakan masukan yang sangat efektif dalam mengendalikan organisme-organisme perusak tanaman atau hasil-hasil pertanian. Sehingga telah mendorong para petani dalam penggunaan pestisida secara berlebihan. Disaat para petani berhadapan langsung dengan pestisida, menjadikan perhatian umumnya petani dan praktisi pertanian 
lebih tertuju pada masalah pengendalian organisme-organisme pengganggu yang menyerang tanaman, sehingga bisa jadi keselamatan kerja dan pencemaran lingkungan yang ditimbulkan, tidak lagi mendapat perhatian yang serius. Penggunaan pestisida menjadi kegiatan aktif dan rutin dilakukan, yang dianggap seolah-olah tidak menimbulkan bahaya bagi penggunanya (Agustina \& Norfai, 2018; Rustiah \& Umriani, 2018). Oleh karena itu, penggunaan pestisida ini menjadi hal yang tidak bisa dipisahkan dalam hal kegiatan pertanian.

Tingginya tingkat pajanan/paparan pestisida disebabkan oleh semakin meningkatnya penggunaan pestisida bagi para pekerja yang kesehariannya bekerja dibagian penyemprotan hama tanaman (Arwin \& Suyud, 2018; Hisyam et al., 2020). Dari beberapa sumber literature, efek toksik yang ditimbulkan akibat dari pajanan/paparan pestisida yang masuk ke dalam darah yaitu dapat menyebabkan terjadinya gangguan system syaraf oleh karena enzim kolinesterase yang dihambat. Adapun dampak negatif yang ditimbulkan akibat kontaminasi dari paparan pestisida ini bisa saja terjadi baik secara akut dan kronik, yaitu melalui 3 jalur, diantaranya melalui kulit (epidermis), pernafasan (inhalation), dan saluran pencernaan (ingestion). Pajanan/paparan secara akut bisa menyebakan keracunan, iritasi di daerah kulit mata, hingga menimbulkan akibat buruk yaitu kematian. Adapun pajanan/pemaparan secara kronik dapat merusak organ-organ dalam, terganggunya sistem syaraf, hingga menyebabkan kanker, dan lain-lain (Direktorat Kesehatan Kerja dan Olahraga Direktorat Jenderal Kesehatan Masyarakat, 2019).

Sifat dasar kandungan bahan kimia dalam pestisida, dampak negatif yang ditimbulkan baik secara langsung maupun tidak langsung bagi kesehatan manusia akibat dari pajanan/paparan penggunaan pestisida, antara lain :

a. Organoklorin $(\mathrm{OK})$

Organoklorin, dianggap sebagai racun kontak dan racun perut. Kehadirannya dapat menyebabkan rusaknya lingkungan dan terganggunya kesehatan masyarakat, dikarenakan sifat persistensinya yang mengendap lama di lingkungan karena sukar terurai. Dampak negatif dari persistensi orgnaoklorin antara lain biomagnifikasi yang membahayakan dan timbulnya masalah baru yaitu keracunan kronik yang juga jangka panjangnya sangat membahayakan. Senyawa toksik untuk ternak termasuk manusia yaitu herbisida senyawa 2,3,7,8-TCDD, pajanannya masuk melalui saluran penernaan atau karena terjadinyan kontak kulit, enzim oksidase yang terinduksi, kuatnya sifat karsinogen, teratogenic hingga dapat menekan reaksi imun. Golongan organoklorin memiliki tingkat toksisitas yang tinggi antara lain sebagai anastesi, racun sistematik dan narkotik. Adapun secara spesifik cara kerjanya yaitu sebagai depressant system pada system saraf pusat (narkosis), mengakibatkan kerusakan pada jaringan liver, bahkan kerusakan pada jaringan ginjal.

b. Organofosfat (OP)

Organofosfat, hamper mirip dengan organoklorin, dimana organofosfat ini dianggap sebagai racun kontak, fumigan, maupun racun perut. Adapun toksisitas dari bahan organofosfat ini akibat paparan senyawa ini antara lain melalui inhibisi enzim kolinesterase pada system syaraf.

c. Karbamat

Karbamat, sifat toksisitasnya serupa dengan golongan organofosfat, dimana toksisitasnya juga melakukan penghambatan pada system syaraf akibat dari aktivitas enzim kolinesterase. (Danudianti, Setiani, \& Ipmawati, 2016; Susanto, Wahyuni, \& Tani, 2021).

Edukasi merupakan salah satu proses belajar yang bertujuan untuk meningkatkan pengetahuan. Tentunya sasaran utama pendidikan kesehatan yaitu meningkatnya keingintahuan akan pentingnya keselamatan dan kesehatan kerja (K3). Adapun pengetahuan yang didapatkan akan menjadi titik tolak perubahan pola pikir dan tingkat pemahaman masyarakat, sehingga perilaku masyarakat dalam hal bertani mengalami banyak perubahan. Harapan akan sosialisasi terpadu secara terintegrasi pada perilaku K3 bagi petani pengguna pestisida, menjadi hal yang sangat penting sebagai upaya pencegahan keracunan pestisida dalam hal edukasi terhadap Perilaku Keselamatan dan Kesehatan Kerja (K3) yang tepat (Akbar, 2019; Utara, 2017). Karena kegiatan pertanian dianggap oleh sebagaian para petani sebagai kegiatan yang sifatnya tertutup, maka segala usaha akan kesehatan para petani pun wajib disesuaikan dengan segala sifat-sifat yang dimiliki masyarakat, baik itu diselenggarakan secara sendiri dan peruntukannya juga untuk kebutuhan sendiri, dalam hal ini baik itu bidang preventif dan kuratif sudah ada usaha-usaha yang dilakukan, termasuk didalamnya penyakit umum yang ditimbulkan, 
terjadinya kecelakaan pada saat bekerja dan penyakit yang ditimbulkan akibat kerja yang dilakukan. Penggunaan Alat Pelindung Diri (APD) merupakan salah satu pengendalian akan dampak negative dari pestisida yang dapat dilakukan oleh para petani dan penyemprot tanaman, hal ini merupakan hubungan linieritas antara Keselamatan dan Kesehatan Kerja (K3) dengan penggunaan pestisida. Adapun jenis APD yang sangat diperlukan bagi pengguna pestisida dalam hal ini para petani dan penyemprot tanaman adalah pakaian yang dapat menutupi tubuh, penutup atau pelindung kepala (topi/helmet), pelindung mata, sepatu boot, masker dan sarung tangan (Afriantoa, 2014; Susanto \& Wahyuni, 2020).

Penggunaan APD saat menangani pestisida atau bekerja denga pestisida, bagi para petani umumnya menganggap APD sebagai hal yang merepotkan dan sangat tidak praktis. Bahkan pengakuan yang mengejutkan dari para petani atau penyemprot tanaman yaitu mereka sudah kebal dan sudah terbiasa dengan bau menyengat yang ditimbulkan dari pestisida, kesemuanya itu disebabkan karena pengetahuan paa petani sangat minim akan keselamatan kerja (Arwin \& Suyud, 2018; Susanto \& Wahyuni, 2020). Selain itu, kebanyakan dari semua kegiatan penyuluhan dan informasi-informasi penting tentang pertanian yang sampai kepada para petani, hanya memberikan pengetahuan sebatas tentang bagaimana standar cara penggunaan pestisida dalam meningkatkan hasil panen para petani.

Uraian di atas merupakan dasar mengapa perlu dilakukan penyuluhan tentang Edukasi K3 di dusun Bangkoa, Kelurahan Gantarang Keke, Kabupaten Bantaeng, untuk meningkatkan pengetahuan tentang bahaya pestisida dan bagaimana menggunakan pestisida yang aman bagi kesehatan, serta penjelasan penggunaan APD sebagai upaya preventif dalam memenuhi syarat dalam prinsip K3. Bentuk kegiatan pengabdian masyarakat ini adalah penyuluhan tentang $\mathrm{K} 3$ dalam penggunaan pestisida.

\section{METODE}

Metode yang disampaikan dalam kegiatan penyuluhan ini adalah :

1. Metode ceramah diawal kegiatan penyuluhan, yang mana menggunakan fasilitator pada saat menyampaikan materi secara verbal.

2. Metode praktek secara langsung cara penggunaan APD yang benar sesuai prinsip K3.

3. Metode diskusi yang dilaksanakan ini membutuhkan interaksi antara peserta penyuluhan dengan fasilitator materi dengan saling bertukar informasi secara lisan dan tatap muka, dengan tujuan agar peserta penyuluhan memahami lebih mendalam materi yang diberikan.

\section{HASIL DAN PEMBAHASAN}

Kegiatan yang dilakukan pada pengabdian kepada masyarakat merupakan usaha dalam menyebarluaskan tentang ilmu pengetahuan dan teknologi yang berkembang saat ini kepada masyarakat. Melalui serangkaian kegiatan pengabdian ini, diharapkan dapat memberikan tambahan ilmu bagi masyarakat, baik itu kegiatan yang dapat meningkatkan perekonomian, kebijakan, dan perubahan yang signifikan akan perilaku individu/masyarakat, baik dalam hal masa sekarang maupun untuk masa yang akan datang (Bantaeng, 2020).

Pelaksanaan kegiatan pengabdian kepada masyarakat di Dusun Bangkoa, Kecamatan Gantarangkeke, Kabupaten Bantaeng berjalan dengan baik dan lancar. Tim Pengabdian Kepada Masyarakat memberikan edukasi K3 dalam penggunaan pestisida. Materi yang disampaikan disusun berdasarkan data observasi lapangan. Selain itu juga berdasarkan penelusuran media berupa buku, artikel, dan jurnal yang relevan dengan pengabdian kepada masyarakat ini. Materi disampaikan melalui presentasi serta penyebaran bahan materi para petani, dan menunjukkan penggunaan APD yang benar. Selanjutnya dibuka sesi tanya jawab, beberapa petani secara bergiliran mengajukan pertanyaanpertanyaan yang langsung mendapatkan jawaban berupa alternatif dan solusi dari pertanyaan yang diajukan.

Masyarakat di Dusun Bangkoa, Kecamatan Gantarangkeke, Kabupaten Bantaeng sebagian besar berprofesi sebagai petani. Mata pencahariannya dengan menanam padi di sawah, bercocok tanam cabai dan kentang di kebun. Dalam melakukan kegiatan bertani sehari-hari petani tidak terlepas dari penggunaan pestisida. Para petani di Dusun Bangkoa paling banyak menggunakan dua golongan pestisida dalam usaha-usaha pertanian yaitu pestisida golongan organopospat dan golongan karbamat, chlorpyrifos (insektisida) dari golongan organopospat, dan mancozeb (fungisida). Untuk jenis tanaman 
yang mana termasuk golongan tanaman sayur-sayuran dan buah-buahan, penggunaan pestisida untuknya hamper selalu dilakukan. Penyemprotan pestisida untuk jenistanaman holtikultura dilakukan sebanyak 2 hingga 3 kali dalam sehari. Terkadang bila terjadi hujan, biasanya penyemprotan dilakukan hanya sekali sehari (Akbar, 2019; Chadijah, Rustiah, \& Munir, 2018; Rustiah, Noor, \& Lukman, 2019).

Sebelum kegiatan pengabdian ini dilakukan, telah dilakukan survei awal kepada para petani penyemprot pestisida di Dusun Bangkoa. Hasilnya didapatkan kebanyakan dalam kegiatan penyemprotan tanaman, para petani hanyak menggunakan alat pelidung diri seadanya, bahkan sangat tidak lengkap. Bahkan mereka hanya menggunakan penutup kepala (topi) dan memakai sepatu bot seadanya, dan terkadang sebagian petani tidak menggunakan pelindung tangan (sarung tangan) pada saat mengaduk pestisida. Seringkali pula ditemukan para petani mengerjakan pengadukan pestisida sambil merokok.

Selain itu pula kebanyakan dari mereka para petani sering mencampur insektisida dan fungisida lebih dari satu jenis dalam sekali kegiatan penyemprotan. Banyaknya jenis insektisida dan fungisida yang dicampurkan merupakan kegiatan penghematan waktu dan tenaga petani. Karena kuranganya tenaga petani yang ahli dan mumpuni, maka semua kegiatan ingin dikerjakan secara cepat dan ringkas, sehingga mereka beranggapan bahwa dengan pencampuran sekaligus, penyemprotan dapat membunuh serangga pemakan tanaman dan jamur pengganggu. Selain itu, anggapan bahwa apabila menggunakan pestisida yang lebih banyak, maka akan semakin ampuh mengatasi pengganggu tanaman seperti organisme.

Pengawasan pestisida dalam hal penyimpanan dan penggunaannya tentang cara pengendalian keracunan yang ditimbulkan oleh pestisida, telah diatur oleh Kementrian Pertanian sesuai PP Nomor 107/Permentan/SR.140/9/2014. Agar tidak terjadi keracuna pestisida, terdapat beberapa tahapan untuk terhindar, antara lain : dalam penanggulangan hama sebaiknya memilih pestisida yang tepat sesuai dengan peruntukannya, dosis pestisida harus disesuaikan dengan aturan yang tertera dilabel kemasan, cara penggunaan pestisida lebih diperhatikan, dan pada saat bersentuhan dengan pestisida agar lebih menggunakan APD yang lengkap dan tepat (Direktorat Kesehatan Kerja dan Olahraga Direktorat Jenderal Kesehatan Masyarakat, 2019).
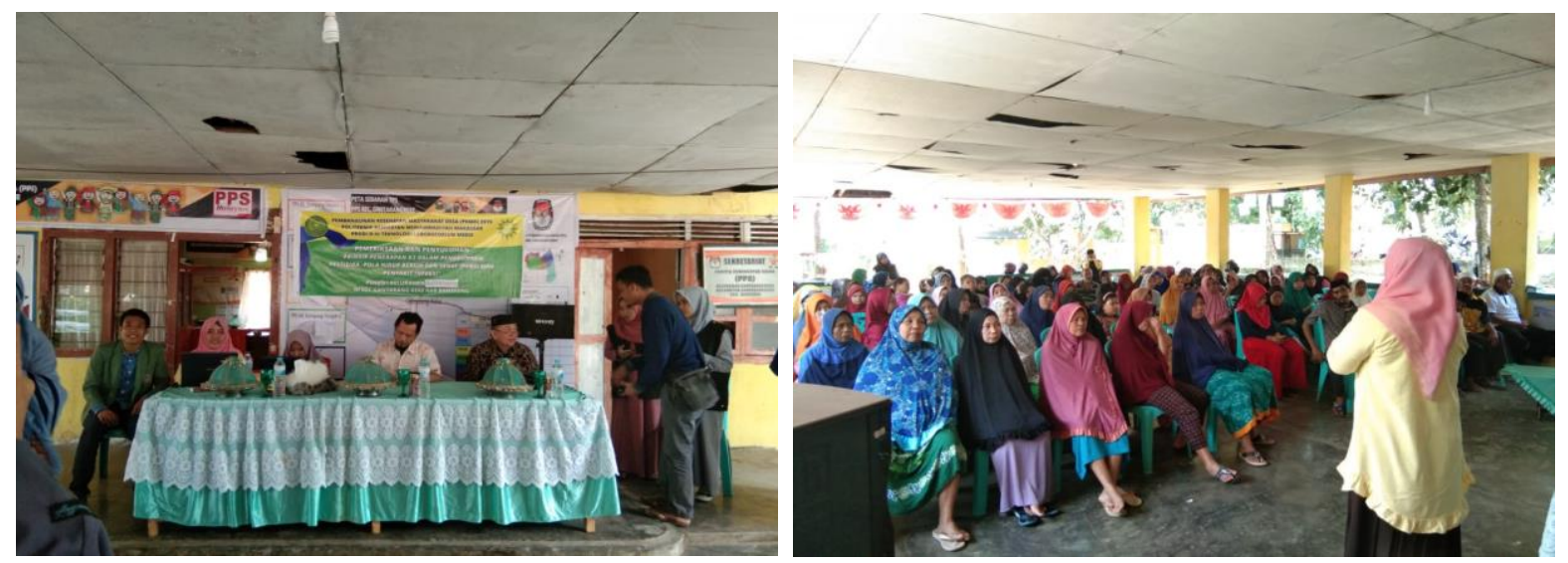

Gambar 1. Penyuluhan kepada masyarakat

Selanjutnya tim penyuluhan memaparkan kepada peserta/para petani bahwa apabila penggunaan pestisida yang tidak disesuaikan dengan aturan perundanganm maka berpotensi menjadi pemicu terjadinya kecelakaan kerja diantaranya keracunan akibat dari paparan pestisida secara langsung. Hasil pemeriksaan laboratorium dengan penegakan diagnose uji cholinesterase, maka tingkatan keracunan yaitu 75 - 100\%, sehingga kadar cholinesterase dikatakan "normal"; jika tingkat keracunan 50 - 75\% termasuk keracunan ringan; sedangkan tingkat keracunan $25-50 \%$ termasuk keracunan sedang; dan 0-25\% digolongkan keracunan berat), itupun setelah melihat gejala-gejala yang ditimbulkan antara lain : sesak nafas, mata berair, penglihatan kabur, detak jantung menjadi cepat, muntah-muntah, pingsan, dan diare) (Agustina \& Norfai, 2018; Susanto et al., 2021) 
Terjadinya ketidakseimbangan kadar enzim cholinesterase dalam darah akibat dari keracunan pajanan pestisida. Bagaimanapun pengetahuan petani dalam menggunakan pestisida menjadi factor penentu dalam mengetahui tingkat pajanan/paparan petani ketika menggunakan pestisida. Terkadang para petani jika tidak menggunakan alat pelindung diri (APD) yang lengkap dan tidak memperhatikan arah angin ketika melakukan penyemprotan, hingga tanpa sadar menyebabkan petani menghirup bau pestisida (Arwin \& Suyud, 2018; Danudianti et al., 2016). Justru akan menimbulkan masalah baru seandainya para petani menggunakan pestisida yang berlebihan, yakni adanya residu pestisida pada produk pertanian, yang justru akan membahayakan keselamatan dan kesehatan kerja bagi para petani dan masyarakat lainnya. Pakaian dan peralatan perlindungan pada saat mau melakukan penyemprotan yang harus disiapkan sejak awal, merupakan salah satu langkah dalam menjaga dan mejamin keselamatan ketika penyemprotan. Selain itu, perlu juga memperhatikan takaran ketika mencampur pestisida. Berbagai mekanisme kandungan kimia yang terdapat dalam pestisida dapat meracuni manusia secara langsung bagi yang sering menggunakan pestisida, bahkan orang yang berada dekat sekalipun dengan pengguna pestisida, antara lain :

1. Kontak langsung dengan kulit dan juga pada pakaian yang terkena percikan atau semprotan pestisida.

2. Jalur pernafasan, akibat terhirup langsung pada saat penyemprotan, dan juga akan terhirup pada orang yang lalu lalang di area penyemprotan.

3. Makanan dan minuman yang telah terpapar/tercemar oleh pestisida, bahkan terkadang petani langsung makan tanpa membersihkan tangan tangan dahulu setelah bersentuhan pestisida (Akbar, 2019; Santoso, 2016).

Tim penyuluhan juga menjelaskan APD yang lengkap dan penggunaan APD yang benar. Penggunaan alat pelindung diri yang lengkap (APD) sesuai dengan konsep Keselamatan dan Kesehatan Kerja (K3) menjadi pilihan terakhir atau last resort dalam pencegahan bahaya kecelakaan yang akan ditimbulkan. Meskipun alat pelindung diri disadari bukan untuk mencegah bahaya kecelakaan (reduce likelihood), akan tetapi diharapkan dapat mengurangi efek atau keparahan kecelakaan yang ditimbulkan (reduce consequences) (Afriantoa, 2014; Susanto \& Wahyuni, 2020).

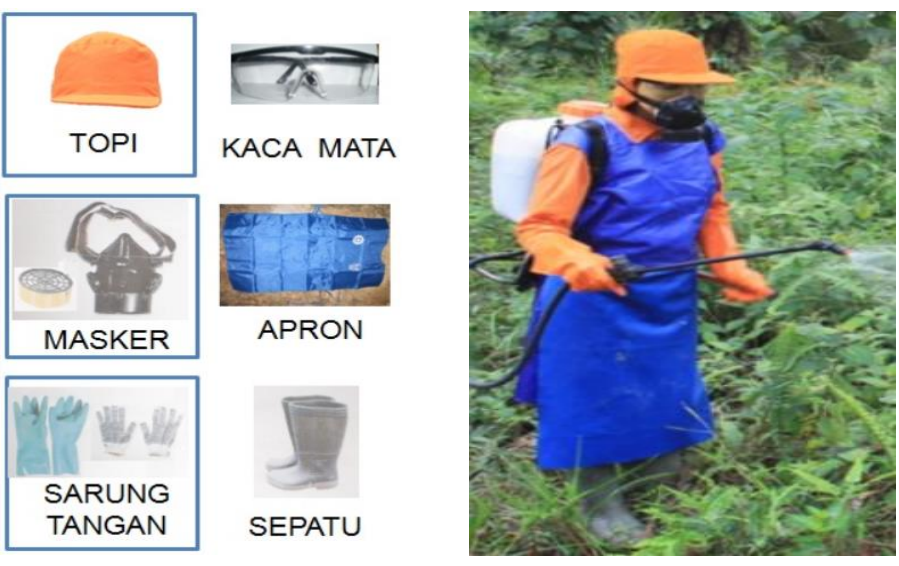

Gambar 2. Peralatan menyemprot lengkap (APD)

Akibat petani kurang memperhatikan penggunaan APD yang lengkap ketika melakukan penyemprotan dengan pestisida, merupakan salah satu penyebab terjadinya keracunan pestisida. Kelengkapan yang perlu diperhatikan saat bekerja dengan penyemprotan adalah penggunaan APD sesuai bahaya dan resiko kerja, sehingga bisa menjaga keselamatan pekerja sendiri serta masyarakat di sekitarnya. Kelengkapan APD yang harus digunakan, antara lain: masker, topi, kaca mata, baju lengan panjang dan celana panjang, celemek, sarung tangan, dan sepatu boot (Afriantoa, 2014; Susanto \& Wahyuni, 2020).

Disarankan kepasa semua para petani atau karyawan yang melakukan penyemprotan agar menggunakan baju APD yang lengkap dengan berlengan panjang, begitupun halnya celana panjang 
ketika akan melakukan menyemprotkan pestisida. Yang utama adalah baju dan celana panjang tersebut adalah pakaian wajib bagi petani untuk bekerja di sawah. Ketika melakukan penyemprotan pestisida sebagian besar petani juga harus menggunakan sepatu boot dari bahan yang elastis, misalnya dari bahan karet atau plastik. Dari hasil survey yang telah dilakukan, diketahui bahwa perilaku petani ketika menggunakan Alat Pelindung Diri (APD) sudah sangat baik, akan tetapi masih diperlukan pengawasan lebih lanjut. Jika penggunaan Alat Pelindung Diri (APD) dilakukan secara tertib oleh para petani dan para karyawan yang melakukan penyemprotan, sangat diharapkan bisa mengurangi resiko para petani akan mengalami keracunan akibat penggunaan pestisida (Afriantoa, 2014; Agustina \& Norfai, 2018; Susanto \& Wahyuni, 2020).

\section{KESIMPULAN}

Adapun kegiatan pengabdian pada masyarakat di Kelurahan Gantarang Keke, Kabupaten Bantaeng, dapat disimpulkan antara lain :

1. Pengetahuan yang luas dan tingkat pemahaman yang cukup bagi masyarakat Kelurahan Gantarang Keke, tentang prinsip penerapan K3 dalam penggunaan pestisida mengalami peningkatan.

2. Pengetahuan akan jenis-jenis pestisida dan dampak negative yang ditimbulkan bagi kesehatan manusia jadi lebih bernilai.

\section{UCAPAN TERIMA KASIH}

Penulis mengucapkan terima kasih kepada Direktur dan Lembaga Penelitian dan Pengabdian kepada Masyarakat (LPPM) Politeknik Kesehatan Muhammadiyah Makassar serta ketua Program Studi D3 Teknologi Laboratorium Medik yang telah membantu berupa dukungan dana dan moril hingga terlaksananya kegiatan pengabdian kepada masyarakat ini dengan baik.

\section{REFERENCES}

Afriantoa, D. (2014). Pengaruh Penyuluhan Terhadap Pengetahuan, Sikap Dan Tindakan Petani Paprika Di Desa Kumbo - Pasuruan Terkait Penggunaan Alat Pelindung Diri ( APD) Dari Bahaya Pestisida. Keselamatan Dan Kesehatan Kerja. Program Studi Kesehatan Masyarakat. Fakultas Kedokteran Dan Ilmu Kesehatan. Universitas Islam Negeri Syarif Hidayatullah. Jakarta, 1-126. Retrieved from http://repository.uinjkt.ac.id/dspace/bitstream/123456789/25507/1/defri afrianto - fkik.pdf

Agustina, N., \& Norfai, N. (2018). Paparan Pestisida terhadap Kejadian Anemia pada Petani Hortikultura. Majalah Kedokteran Bandung, 50(4), 215-221. https://doi.org/10.15395/mkb.v50n4.1398

Akbar, F. K. R. (2019). Analisis Risiko K3 Pemberantasan Hama Pekerjaan Pertanian Jeruk. Journal of Public Health Research and Community Health Development, 3(1), 01. https://doi.org/10.20473/jphrecode.v3i1.13067

Arwin, N. M., \& Suyud, S. (2018). Pajanan pestisida dan kejadian anemia pada petani holtikultura di Garut. Berita Kedokteran Masyarakat, 32(7), 245. https://doi.org/10.22146/bkm.12313

Bantaeng, K. (2020). Lontara abdimas. 1(1), 1-5.

Chadijah, S., Rustiah, W. O., \& Munir, M. I. D. (2018). Determination of the optimum concentration cellulose baggase in making film bioplastic. Journal of Physics: Conference Series, 979(1). https://doi.org/10.1088/1742-6596/979/1/012026

Danudianti, Y., Setiani, O., \& Ipmawati, P. (2016). Analisis Faktor Â Faktor Risiko Yang Mempengaruhi Tingkat Keracunan Pestisida Pada Petani Di Desa Jati , Kecamatan Sawangan, Kabupaten Magelang, Jawa Tengah. Jurnal Kesehatan Masyarakat (e-Journal), 4(1), 427-435.

Direktorat Kesehatan Kerja dan Olahraga Direktorat Jenderal Kesehatan Masyarakat, K. K. R. (2019). Pedoman Pestisida Aman dan Sehat di Tempat Kerja Sektor Pertanian (Bagi Petugas Kesehatan). (November 2016). Retrieved from https://www.researchgate.net/profile/HanifaDenny/publication/332528454_Pedoman_Pestisida_Aman_dan_Sehat_di_Tempat_Kerja_Sektor _Pertanian/links/5cb9c499a6fdcc1d499ff0f7/Pedoman-Pestisida-Aman-dan-Sehat-di-TempatKerja-Sektor-Pertanian.pdf?origin=publicati

Hisyam, M., Adelia W, A., Afifa R., A., Dewi P, E., Qurrota A, L., Zulfikar F., M., ... Setiawan, C. D. (2020). Pengetahuan Dan Pola Penggunaan Insektisida Antinyamuk Oleh Ibu Rumah Tangga Di 
Kelurahan Mojo Surabaya. Jurnal Farmasi Komunitas, 6(2), 38. https://doi.org/10.20473/jfk.v6i2.21841

Rustiah, W., Noor, A., \& Lukman, M. (2019). Distribution Analysis of Nitrate and Phosphate in Coastal Area: Evidence from Pangkep River, South Sulawesi. 7(1), 9-17. https://doi.org/10.20956/ijas.v7i1.1835

Rustiah, W., \& Umriani, N. (2018). Uji Aktivitas Antioksidan Pada Ekstrak Buah Kawista (Limonia Acidissima) Menggunakan Spektrofotometer UV-Vis. Indo. J. Chem. Res., 6(1), 22-25. https://doi.org/10.30598//ijcr.2018.6-wao

Santoso, E. (2016). FAKTOR YANG BERHUBUNGAN DENGAN PAPARAN PESTISIDA PADA PEKERJA CHEMIS ( PENYEMPROTAN ). 1(June), 88-93.

Susanto, B. H., \& Wahyuni, I. D. (2020). Edukasi Pemakaian Alat Pelindung Diri (Apd) Pada Petani Penggunaan Pestisida. Seminar Nasional Hasil Pengabdian Kepada Masyarakat, (Ciastech), $1173-1178$.

Susanto, B. H., Wahyuni, I. D., \& Tani, K. (2021). Edukasi Perilaku Petani penyemprotan pestisida dalam pengaplikasian di lapangan kelompok tani. Media Husada Journal of Community Servic, 1(1), 12-18. Retrieved from https://ojs. widyagamahusada.ac.id

Utara, U. S. (2017). Universitas Sumatera Utara. 